Article

\title{
Dissimilar Responses of Ancient Grapevines Recovered in Navarra (Spain) to Arbuscular Mycorrhizal Symbiosis in Terms of Berry Quality
}

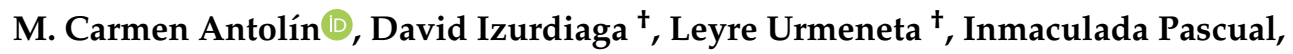 \\ Juan José Irigoyen $D$ and Nieves Goicoechea * $D$ \\ Unidad Asociada al CSIC (EEAD, Zaragoza, ICVV, Logroño), Grupo de Fisiología del Estrés en \\ Plantas (Departamento de Biología Ambiental), Facultad de Ciencias, Universidad de Navarra, c/Irunlarrea 1, \\ 31008 Pamplona, Navarra, Spain; cantolin@unav.es (M.C.A.); dizurdiaga.1@alumni.unav.es (D.I.); \\ lurmeneta@alumni.unav.es (L.U.); ipascual@unav.es (I.P.); jirigo@unav.es (J.J.I.) \\ * Correspondence: niegoi@unav.es; Tel.: +34-948-425600 (ext. 806489) \\ + These authors contributed equally to the work.
}

Received: 4 March 2020; Accepted: 27 March 2020; Published: 29 March 2020

check for updates

\begin{abstract}
The exploitation of genetic diversity within agricultural plants, including grapevine, is suggested as a valuable tool to cope with the negative impacts of climate change on yield and crop quality. In some winegrowing regions of Europe, there is a renewed interest in knowing the grapevine genetic resources available, focusing on the prospection, recovery, and study of ancient cultivars typical of every zone. Grapevines are naturally associated with arbuscular mycorrhizal fungi (AMF), which provide some benefits to the host plant, although such effects depending on many factors, including variety. Therefore, the aim of this research was to characterize the potential fruit quality of eight old grapevine varieties recovered in Navarre (northeastern of the Iberian Peninsula), associated or not with AMF. The study was carried out on fruit-bearing cuttings grown under controlled conditions (greenhouse). Overall, AMF inoculation reduced bunch and berry mass, as well as phenolic content in fruits. In some varieties, AMF association improved some berry traits by increasing the concentrations of soluble solids and anthocyanins; in others, berry colour, total phenolic and anthocyanin content were diminished in AMF-inoculated plants. The results, therefore, suggest that intraspecific diversity of old grapevines could include different abilities to respond to arbuscular mycorrhizal symbiosis.
\end{abstract}

Keywords: anthocyanins; intraspecific diversity; mycorrhizal association; old grapevine varieties; phenolic compounds; soluble sugars

\section{Introduction}

Grapevine (Vitis vinifera L.) is one of the most extensively cultivated species with a total global surface of 7.4 million hectares of vineyards, most of them dedicated to the production of wine (292 million hectoliters in 2018). Spain produced 44.4 million hectoliters, which represent, respectively, $15 \%$ and $23.5 \%$ of the world and the European wine production [1]. One of the most important consequences linked to the increased ambient temperatures predicted for the end of the present century is the production of unbalanced red wines with enhanced alcohol levels, decreased acidities and modified organoleptic properties such as reduced colour due to the decoupling effect of anthocyanins and sugars accumulated in the fruits [2,3].

Among the strategies suggested to cope with the next challenges of agriculture (e.g., climate change, sustainable production and/or competition in a global market) is the exploitation of the intraspecific genetic diversity within crops, including grapevines [4]. Thus, in some grapevine growing 
regions of the Mediterranean zone, this approach is generating a renewed interest to know the genetic resources available in this species, both in collections and isolated in old vineyards [5-7]. Therefore, the prospection, recovery and study of ancient cultivars are becoming very important to preserve the genetic resources of a region. In Spain, there is an increasing interest to identify and recover forgotten ancient varieties to give a response to the market demanding regional typicity and diversity. These old cultivars show a very narrow regional distribution, but studies focused on their genetic and oenological characterization are showing new sorts of wines that can identify productions from local or small geographical regions, providing them with special recognitions [6,8-11]. Moreover, this trend attempts to counterbalance the rapid loss of genetic diversity in vineyards and could be a very positive strategy to maintain higher genetic diversity, as well as product diversity in the markets [12].

Another strategy which may alleviate the negative effects of the elevated air temperatures on the quality of red wines is to implement techniques based on the exploitation of carbon and nutritional competition between developing grapevine organs [13]. Under field conditions, grapevines are associated with arbuscular mycorrhizal fungi (AMF) [14,15]. The presence of AMF colonizing grapevines roots benefits nutrient uptake and plant vigour [16,17], but also, influence berry hormonal status and fruit ripening [18]. Several studies reported that AMF may modulate the synthesis of secondary metabolites in host plants, including grapevines [19]. In fact, it has been shown that the phenolic and anthocyanin accumulation of berries was increased in AMF colonized plants [18,20], which could result in wines with improved nutritional and nutraceutical value [21]. These positive effects have been related to differential activity of diverse enzymes in mycorrhizal plants leading to the production of terpenoids, flavonoids and polyphenols [22-24]. Moreover, the association of grapevines with AMF can induce the accumulation of aminoacids in berries, including those responsible for the aromatic characteristics of wines [25]. However, the AMF also represents an additional sink of carbon fixed by the host plant, because these fungi need plant sugars for their own growth and functioning. It has been calculated that the carbon flow from the host to AMF in roots may vary from 4 to $20 \%$ of total photoassimilates [26] depending on the relative activity, hierarchy and developmental stage of the different sinks within the plant [27]. To our knowledge, the impact of mycorrhizal inoculation to berry quality of ancient grapevine varieties is still unexplored.

Navarre, in the northeastern of the Iberian Peninsula, is an important grape-growing region in Spain giving high-quality wines. In 2018, this region produced 0.83 million hectoliters of wine and represented $2 \%$ of Spain wine production [28]. The prospection and recovery of old varieties of Navarre started in 2002 with the aim of preserving the genetic richness of old vineyards. However, it is mandatory to check the agronomical and enological traits of these varieties to establish its potential to produce quality wines. This evaluation should include the study of the phenology, plant development, yield, and fruit quality parameters. Moreover, there is an increasing interest from winegrowers for a better knowledge of the possible services which AMF could provide with respect to the adaptation to climate evolution and development towards sustainable viticulture. Therefore, the aim of this research was to characterize the potential fruit quality of eight old grapevine varieties isolated in Navarre, comparing plants inoculated or not with AMF. Potted vines were used to ensure that all the varieties experienced the same conditions and to control the application of AMF.

\section{Materials and Methods}

\subsection{Biological Material}

Dormant 400-500 mm long Vitis vinifera (L.) cuttings from different ancient grapevine varieties were collected during the winter of 2017 from an experimental vineyard of the Estación de Viticultura y Enología de Navarra (EVENA) (Olite, Spain). Some agronomic traits of the selected ancient varieties are shown in the Table 1. Cuttings were prepared for fruit-bearing according to the steps originally outlined by [29] with some modifications previously described by [20]. Rooted cuttings were transplanted in 
6.5-L plastic pots containing a mixture of vermiculite-sand-light peat $(2.5: 2.5: 1, \mathrm{v}: \mathrm{v}: \mathrm{v})$. The peat was previously sterilised at $100^{\circ} \mathrm{C}$ for $1 \mathrm{~h}$ on 3 consecutive days.

Table 1. Summary of the agronomic characteristics of the ancient grapevine varieties used in this study. Data provided by the Estación de Viticultura y Enología de Navarra (EVENA) (Olite, Spain) were collected in 2018 from plants grown in the vineyard.

\begin{tabular}{cccccc}
\hline Variety & Clone & Code & Reproductive Cycle & Bunch Mass (g bunch $\left.{ }^{-1}\right)$ & Berry Mass (g) \\
\hline Tempranillo & T23 & TEMP & Medium & 329 & 2.58 \\
Vidadillo & T75 & VID & Medium & 326 & 2.29 \\
Grand Noir & T48 & GN & Medium & 173 & 1.27 \\
Tinto Velasco & T73 & TV & Medium & 158 & 2.13 \\
Graciano & T72 & GRA & Medium & 85 & 1.17 \\
Morate & T71 & MO & Long & 216 & 1.65 \\
Pasera & T85 & PAS & Long & 449 & 2.63 \\
Ambrosina & T46 & AMB & Long & 219 & 1.74 \\
\hline
\end{tabular}

At transplanting, half of the plants $(+\mathrm{M})$ were inoculated with the mycorrhizal inoculum Bioradis Gel (Bioera SLU, Tarragona, Spain). The inoculum was a mixture of five AMF (Septoglomus deserticola, Funneliformis mosseae, Rhizoglomus intraradices, Rhizoglomus clarum, and Glomus aggregatum), and contained 100 spores per $g$ of inoculum and a mixture of rhizobacteria belonging to the genera Bacillus and Paenibacillus $\left(2 \times 10^{6} \mathrm{CFU} \mathrm{g}{ }^{-1}\right)$. Mycorrhizal inoculum was produced by using trap plants for each type of mycorrhizal fungus, and then all AMF were mixed according the commercial formulation. The final commercial formulation included plant growth promoting rhizobacteria (PGPRs) because they can act synergistically with AMF to benefit host plants (Hernández, A. from Bioera SLU, personal communication). The microbial preparation was diluted in distilled water (1:20) to ensure that each plant could receive $1 \mathrm{~g}$ of product. The inoculation was performed by submerging roots of fruit-bearing cuttings in the Bioradis Gel for $15 \mathrm{~min}$. In order to restore rhizobacteria and other soil free-living microorganisms accompanying AMF, uninoculated plants (-M) were submerged for $15 \mathrm{~min}$ in a filtrate of the abovementioned mycorrhizal inoculum. The filtrate was obtained by passing mycorrhizal inoculum through a layer of 15-20 $\mu \mathrm{m}$ filter paper with particle retention of $2.5 \mu \mathrm{m}$ (Whatman 42; GE Healthcare, Little Chalfont, UK). Microorganisms accompanying AMF play an important role in the uptake of soil resources as well as on the infectivity and efficiency of AMF isolates [30] and some PGPR, such as Bacillus spp. isolated from vineyards are known to benefit the basal immunity of grapevines against some pathogens [31]. By restoring the bacterial component of the mycorrhizal inoculum in the rhizosphere of the $-\mathrm{M}$ plants, differences between $-\mathrm{M}$ and $+\mathrm{M}$ plants are expected to be mainly due to the presence of AMF associated with $+\mathrm{M}$ plants.

\subsection{Experimental Design}

Fruit-bearing cuttings grew in a greenhouse, where growth conditions were $25 / 15^{\circ} \mathrm{C}$ and $50 / 90 \%$ relative humidity (day/night) regime and natural daylight (photosynthetic photon flux density, PPFD, was on average $850 \mu \mathrm{mol} \mathrm{m}{ }^{-2} \mathrm{~s}^{-1}$ at midday) supplemented with high-pressure sodium lamps (SON-T Agro Phillips, Eindhoven, Netherlands) to extend the photoperiod up to $15 \mathrm{~h}$ and ensure a minimum PPFD of $350 \mu \mathrm{mol} \mathrm{m}^{-2} \mathrm{~s}^{-1}$ at the level of the inflorescence. Humidity and temperature were controlled using M22W2HT4X transmitters (Rotronic Instrument Corp., Hauppauge, USA). PPFD was monitored with a LI-190SZ quantum sensor (LI-COR, Lincoln, USA). Under these conditions, bud-break took place after one week and only a single flowering stem was allowed to develop on each plant during growth. Fruit set (Eichhorn and Lorenz (E-L) growth stage 27) [32] took place one month after bud-break. Then, vegetative growth was controlled by pruning, thus maintaining a leaf area to fruit mass ratio enough for berry ripening in all the varieties (12-14 leaves per plant) [33].

Plants were watered twice per day with a nutrient solution with phosphorus level $0.30 \mathrm{mM}$ alternated with water to maintain the soil water content at $80 \%$ of pot capacity [34]. When fruit maturity 
was reached (E-L 38 stage) plants were harvested separately based on sugar level (ca. $21-23^{\circ}$ Brix) from berry subsamples (2-3 berries) taken weekly. There were 3 or 4 replicates for each combination of treatment $(+\mathrm{M}$ and $-\mathrm{M})$ and variety.

\subsection{Plant Determinations}

The length of phenological phases was recorded independently for each plant as the number of days from fruit set (E-L 27 stage) to when half of the berries of the bunch were coloured (E-L 35 stage, veraison), and from veraison (E-L 35 stage) to maturity (E-L38 stage). At harvest, bunches were weighed, and 10 berries from each plant were collected and weighed individually. Mean fresh berry mass was determined and berries were separated into skin and flesh. The remaining berries were frozen at $-20^{\circ} \mathrm{C}$ for further analysis. The relative skin mass was calculated as the quotient between skin fresh matter (FM) and total berry FM expressed as a percentage.

For determining mycorrhizal colonization, root samples were cleared and stained following the procedure described in [35]. A potassium hydroxide solution (10\% w:v) was added to the roots which were placed in an oven at $70{ }^{\circ} \mathrm{C}$ for $2 \mathrm{~h}$. After rinsing with water, roots were clarified by the addition of $\mathrm{H}_{2} \mathrm{O}_{2}(3 \% \mathrm{v}: \mathrm{v})$ and subsequent washing with water. Then, they were acidified by soaking in $\mathrm{HCl}(1 \%$ $\mathrm{v}: \mathrm{v})$ for $5-15 \mathrm{~min}$ and stained in a solution of methyl blue: lactic acid ( $1 \% \mathrm{w}: \mathrm{v})$ at $70{ }^{\circ} \mathrm{C}$ for $1 \mathrm{~h}$. Stained roots were stored in a mixture of glycerol, water, and $\mathrm{HCl}$ 1\% (500:450:50, v:v:v) until quantification. The percentage of mycorrhizal colonization was determined under a stereoscopic microscope $(15-20 \mathrm{x}$ overall magnification) by the plate intersection method (100-130 intersections for each sample, one sample per plant [36].

\subsection{Berry Determinations}

A subsample of 25 berries was crushed and then extracts were centrifuged at $6000 \times g$ at $4{ }^{\circ} \mathrm{C}$ for $10 \mathrm{~min}$. The supernatant was used for the following determinations: total soluble solids measured with a temperature-compensating refractometer (Zuzi model 315; Auxilab, Beriáin, Spain) and expressed as ${ }^{\circ}$ Brix; must $\mathrm{pH}$ measured with a $\mathrm{pH}$ meter (Crison Instruments, Barcelona, Spain) standardised to $\mathrm{pH}$ 7.0 and 4.0; titratable acidity measured by titration with $\mathrm{NaOH}$ according to International Organisation of Vine and Wine methods [37]; and L-malic acid measured by an enzymatic method (Enzytec L-Malic Acid; R-Biopharm, Darmstadt, Germany).

Another 25-berry subsample per plant was taken for the analysis of anthocyanins, total phenols and chromatic properties. Total and extractable anthocyanins were determined according to the procedure described by [38]. Two samples of the non-filtered, crushed grape homogenate were macerated for $4 \mathrm{~h}$ at pH 1 (hydrogen chloride) and pH 3.2 (tartaric acid), respectively. Then, the macerated samples were centrifuged at $6000 \times g$ at $4{ }^{\circ} \mathrm{C}$ for $10 \mathrm{~min}$. Total and extractable anthocyanins were determined in both supernatants (macerated at $\mathrm{pH} 1$ and $\mathrm{pH}$ 3.2) according to [39] by reading absorbance at $520 \mathrm{~nm}$. Both data were used to calculate the cellular extractability (EA) of anthocyanins [40]. The seed maturity (SM) index was calculated by the Glories method [40]. Total polyphenol index (TPI) was calculated by the absorbance reading at $280 \mathrm{~nm}$ in the supernatant obtained after maceration at $\mathrm{pH} 3.2$ [41]. Colour density was calculated by adding the absorbance readings at 420,520 and $620 \mathrm{~nm}$, whereas tonality index was determined as the ratio of absorbance readings at 420 and $520 \mathrm{~nm}$ of the samples extracted at $\mathrm{pH} 3.2$ [42].

\subsection{Statistical Analyses}

Statistical analyses were carried out using the Statistical Package for the Social Sciences (SPSS) software (SPSS Inc., Chicago, IL, USA) version 22.0 for Windows. Data were analyzed by principal component analysis (PCA) to determine general trends in the different samples. Bartlett's test of sphericity and the Kaiser-Meyer-Olkin (KMO) test were calculated to assess the suitability of the data to PCA. Then, an analysis of variance (ANOVA) was employed once proved that the data met the assumptions of normality (Shapiro-Wilks's test) and homoscedasticity (Levene's test) with a threshold 
of 0.05 . When ANOVA was statistically significant $(p \leq 0.05)$, the differences among groups were tested with a Duncan test post-hoc test. Results were considered statistically significant if $p \leq 0.05$.

\section{Results}

The ancient grapevine varieties tested in this study have significant diversity for some agronomic traits such as length of cycle, yield, bunch mass and berry mass (Table 1). Under field conditions, Tempranillo (TEMP), Vidadillo (VD), Grand Noir (GN), Tinto Velasco (TV) and, Graciano (GRA) were characterized by a shorter reproductive cycle than Morate (MO), Pasera (PAS) and, Ambrosina (AMB). Under our experimental model, the inoculation of the ancient varieties with AMF resulted in a quite similar percentage of mycorrhizal colonization of the roots among them, ranging between 75 and $91 \%$ (Figure 1). Solely, AMB attained a mycorrhization percentage significantly higher than that of GRA and MO.

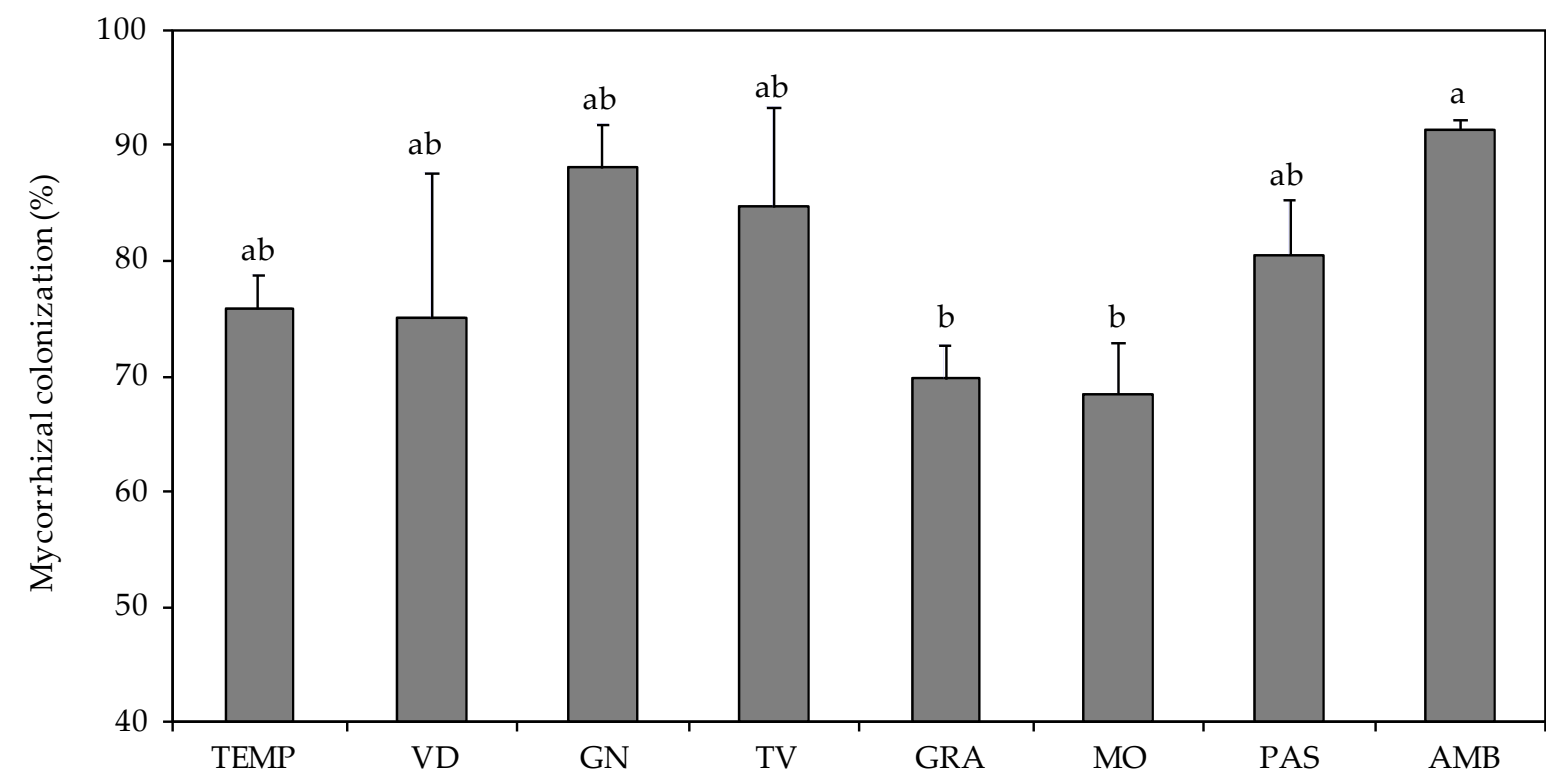

Figure 1. Percentage of mycorrhizal colonization of roots from fruit-bearing cuttings of ancient grapevine varieties. Values are means \pm S.E. $(n=3)$. Bars topped by the same letter do not differ significantly $(p>0.05)$ according to Duncan's test. The variety labels can be found in Table 1 .

\subsection{Principal Component Analysis}

Considerable descriptive data regarding yield and fruit quality were collected from eight old grapevine varieties recovered in Navarre (Spain). The principal component analysis (PCA) was conducted to determine general trends in the different genotypes and treatments. In particular, this analysis provided a tool to describe the main differences among the varieties studied in terms of plant characteristics and berry composition, as well as to identify the variables involved in their response to AMF association, thus helping to elucidate which of the genotypes studied performed better with the AMF inoculation. Our hypotheses were: i) the varieties studied performed differently according to the parameters analyzed; ii) the association with AMF can modulate in a different way the performance of the varieties. Figure 2 shows the score plot obtained by PCA, where samples of each grapevine variety, either inoculated or not, are grouped in the plot of the first and second principal components: PC1 versus PC2. Here, PC1 accounted for about $38 \%$ of the total variance, while PC 2 covered $15 \%$. AMF inoculated or uninoculated plants could not be clearly distinguished (Figure 2a). However, varieties were separated along PC1 where a clear distinction was observed between VD and MO with respect to GRA and TV. The loading plot highlighted the importance of the grape anthocyanin content (total and extractable anthocyanins) and anthocyanin to soluble solids ratio, to a larger extent, but also fruit set-maturity cycle, bunch mass, must $\mathrm{pH}$, titratable acidity, to a lesser extent, in explaining variance 
across PC1 (Figure 2b). PC2 allowed establishing a difference among varieties in relation to TPI and the total soluble solids. According to this result, GRA and TV stood out for having a higher anthocyanin content and anthocyanin to sugar ratio, whereas $\mathrm{VD}$ and $\mathrm{MO}$ were characterized by presenting higher must $\mathrm{pH}$ and longer fruit set to maturity period.

With the aim to understand the different performances of varieties within each treatment (inoculated with AMF or uninoculated) two more PCA were conducted (Figure 3). Figure 3a,b show the score and the loading plots generated for uninoculated (-M) treatment, while Figure $3 c$, d correspond to AMF inoculated condition $(+M)$. Within uninoculated treatment, the varieties were separated both along PC1, which explained the $35.18 \%$ of the variance, and PC2, which covered $18.65 \%$ (Figure $3 a$ ). GRA and PAS were the most differentiated varieties due to PC1 according the content of extractable anthocyanins and relative skin mass (both higher in GRA), as well as, bunch mass and length of phenological development (both higher in PAS) (Figure 3b). On the other hand, the two first principal components from data of AMF inoculated treatment covered $48.30 \%$ and $16.76 \%$ of the total variance, respectively (Figure 3c). Interestingly, a higher dispersion among varieties was observed in this treatment compared with the uninoculated one. In particular, VD was more separated from the rest of varieties by PC1 than in the analysis of uninoculated treatment. Such segregation was related to a lower content of total and extractable anthocyanins, extractability (EA), titratable acidity, and lower anthocyanins to soluble solids ratio, as well as a longer fruit set to maturity period and $\mathrm{pH}$ (Figure 3d). In addition, PC2 established a higher difference between TV and the rest of varieties, which was associated with lower TPI values in this cultivar. 


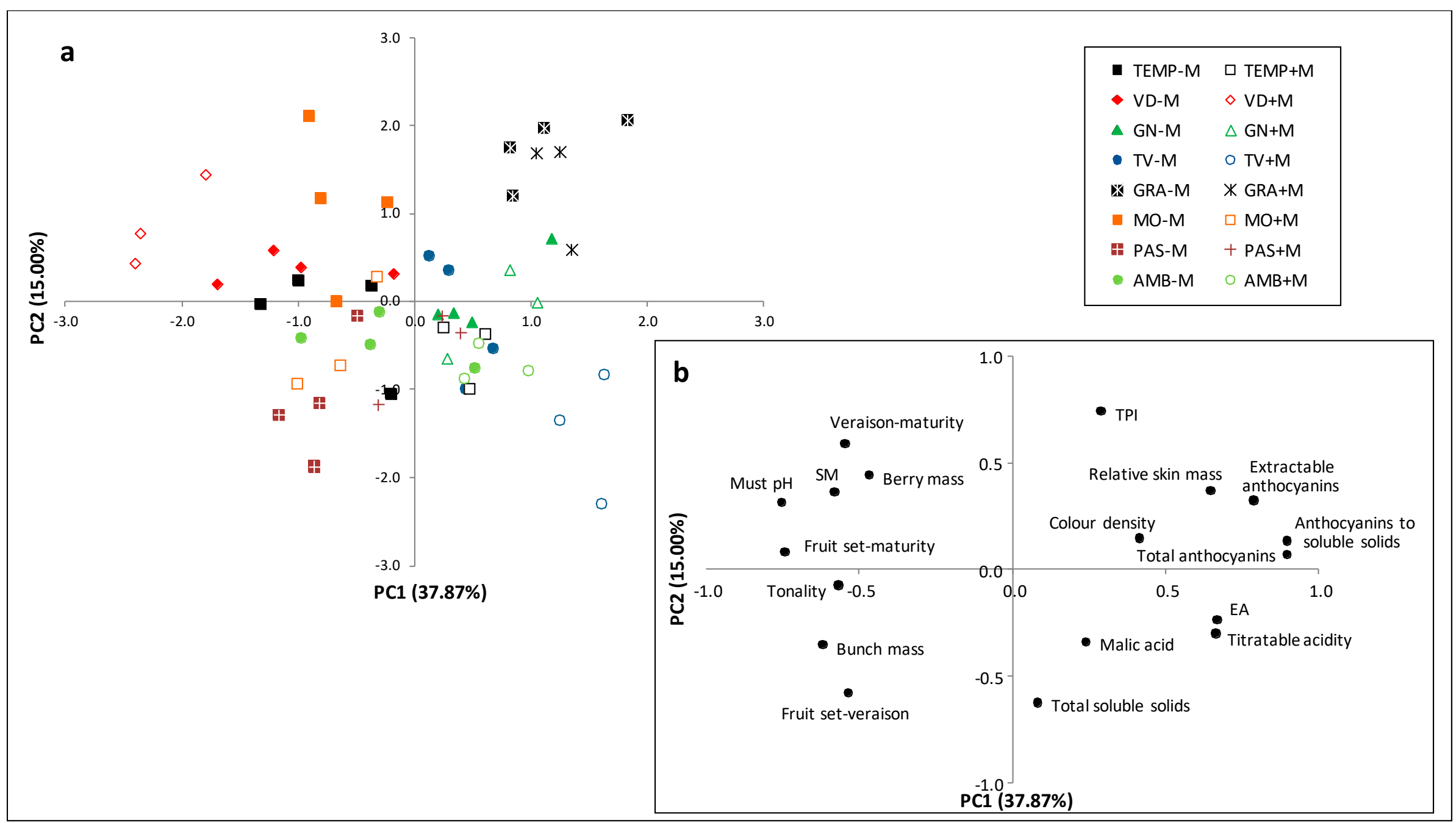

Figure 2. Principal component analysis score (a) and loading plot (b) obtained from the statistical analysis of plant and berry characteristics data of 56 studied samples from fruit-bearing cuttings of some ancient grapevine varieties inoculated with arbuscular mycorrhizal fungi $(+\mathrm{M})$ or uninoculated $(-\mathrm{M})$. 


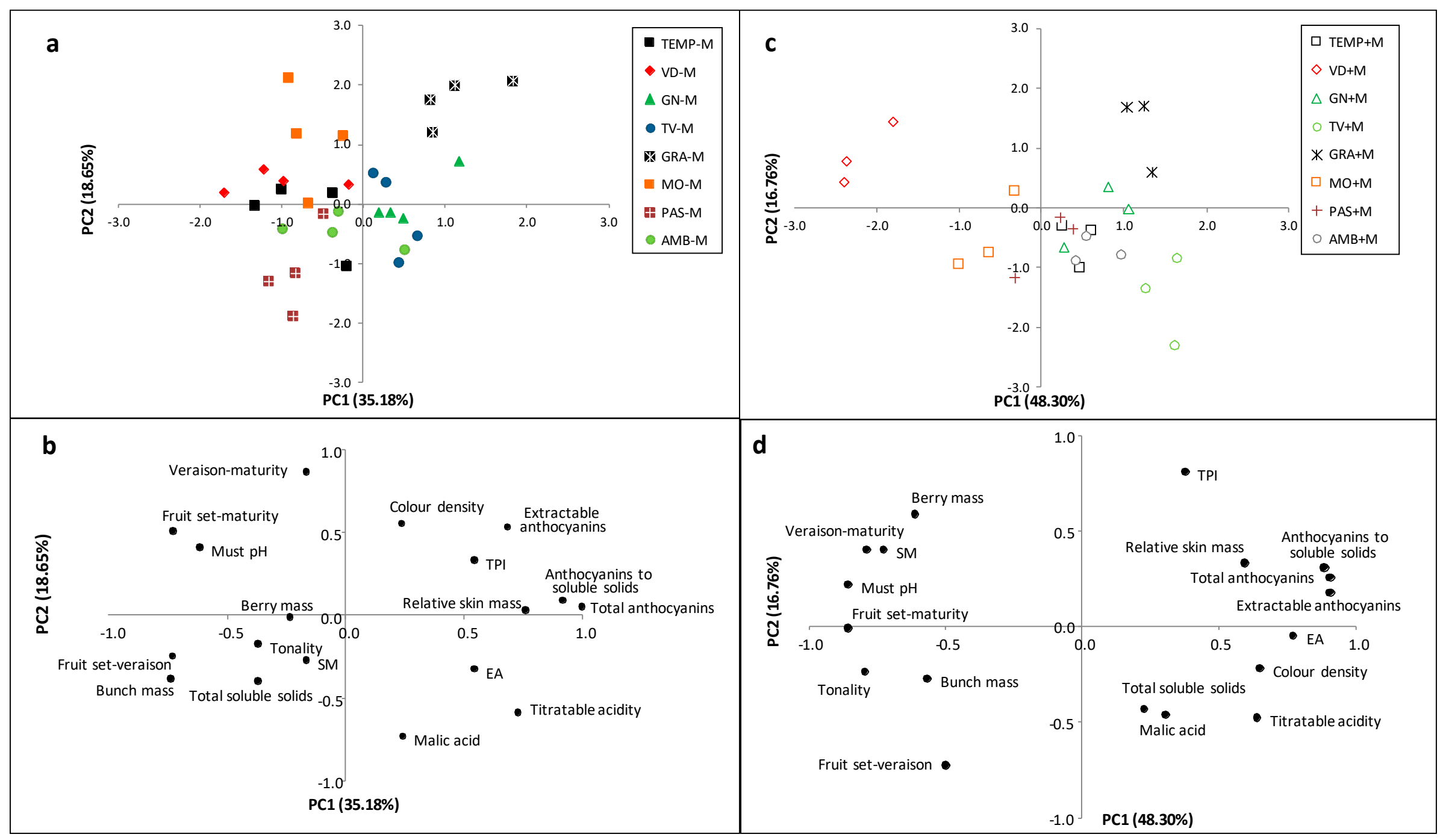

Figure 3. Principal component analysis score $(\mathbf{a}, \mathbf{c})$ and loading plot $(\mathbf{b}, \mathbf{d})$ obtained from the statistical analysis of plant and berry characteristics data of 28 studied samples from fruit-bearing cuttings of some ancient grapevine varieties inoculated with arbuscular mycorrhizal fungi (a,b) or uninoculated (c,d). 


\subsection{Plant Characteristics}

Regarding phenology, under our experimental conditions, the variety was the main factor influencing phenology (Table 2). However, the length of ripening was affected by the interaction $\mathrm{V} \times \mathrm{M}$ $(p<0.001)$ being VD and AMB the varieties in which mycorrhizal colonization significantly modified the berry ripening period (Figure 4).

Table 2. Main effects and their interaction on phenology from fruit-bearing cuttings of ancient grapevine varieties inoculated with arbuscular mycorrhizal fungi $(+M)$ or non-inoculated $(-M)$. The variety labels can be found in Table 1 .

\begin{tabular}{|c|c|c|c|}
\hline Varieties & $\begin{array}{l}\text { Fruit Set-Veraison } \\
\text { (Days) }\end{array}$ & $\begin{array}{l}\text { Veraison-Maturity } \\
\text { (Days) }\end{array}$ & $\begin{array}{c}\text { Fruit set-Maturity } \\
\text { (Days) }\end{array}$ \\
\hline \multicolumn{4}{|l|}{ Main effects } \\
\hline \multicolumn{4}{|l|}{ Variety $(V)$} \\
\hline TEMP & $83 \mathrm{ab}$ & $14 \mathrm{~d}$ & $98 \mathrm{bcd}$ \\
\hline VID & $84 \mathrm{ab}$ & $49 \mathrm{a}$ & $133 \mathrm{a}$ \\
\hline GN & $74 b$ & $24 \mathrm{~cd}$ & $100 \mathrm{bcd}$ \\
\hline TV & $76 \mathrm{~b}$ & $13 \mathrm{~d}$ & $88 \mathrm{~d}$ \\
\hline GRA & $62 c$ & $34 \mathrm{bc}$ & $96 \mathrm{~cd}$ \\
\hline $\mathrm{MO}$ & $78 \mathrm{ab}$ & $41 \mathrm{ab}$ & $115 \mathrm{~b}$ \\
\hline PAS & $88 \mathrm{a}$ & $22 \mathrm{~cd}$ & $107 \mathrm{bc}$ \\
\hline $\mathrm{AMB}$ & $82 \mathrm{ab}$ & $28 \mathrm{c}$ & $111 \mathrm{bc}$ \\
\hline \multicolumn{4}{|l|}{ Mycorrhization (M) } \\
\hline$-\mathrm{M}$ & $77 \mathrm{a}$ & $28 \mathrm{a}$ & $103 \mathrm{a}$ \\
\hline$+\mathrm{M}$ & $81 \mathrm{a}$ & $29 \mathrm{a}$ & $110 a^{1}$ \\
\hline \multicolumn{4}{|l|}{ ANOVA $^{2}$} \\
\hline Variety (V) & $* * *$ & $* * *$ & $* * *$ \\
\hline Mycorrhization (M) & ns & ns & ns \\
\hline $\mathrm{V} \times \mathrm{M}$ & ns & $* * *$ & $* * *$ \\
\hline
\end{tabular}




\section{Fruit set-veraison}

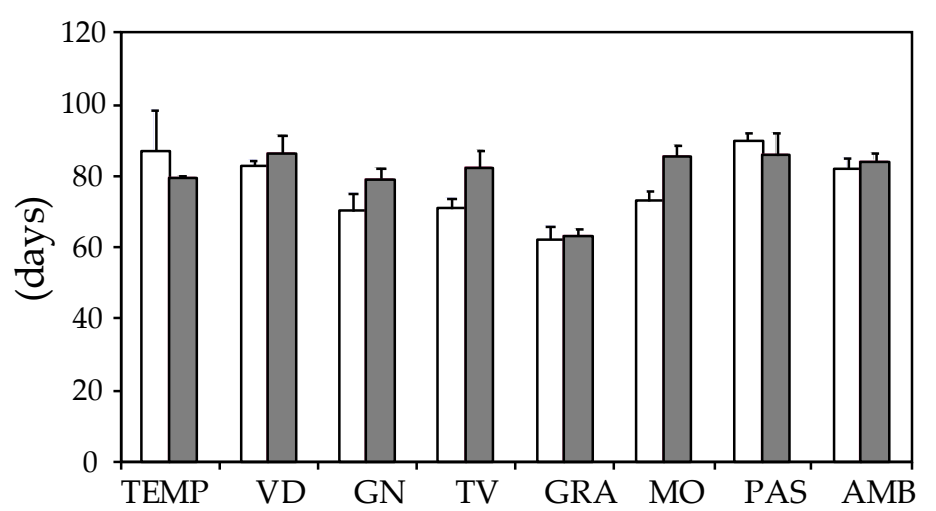

Veraison-maturity

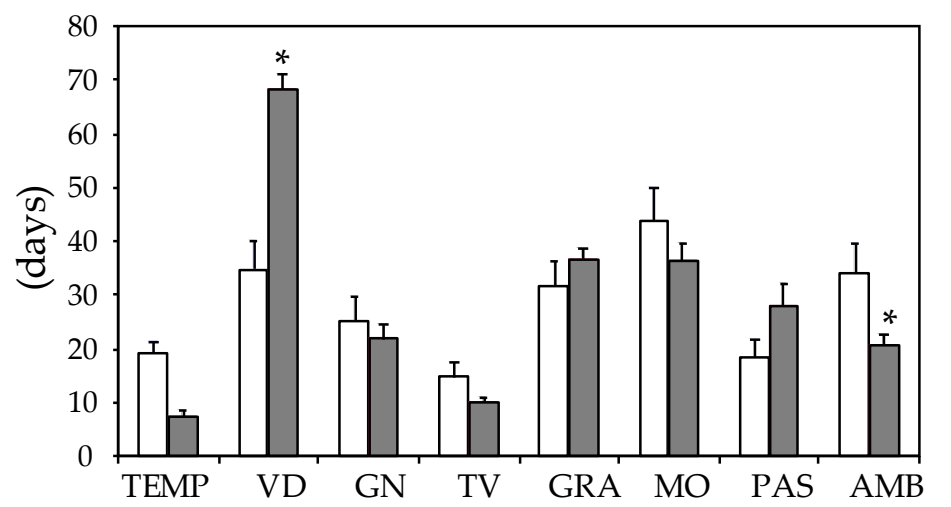

Fruit set-maturity
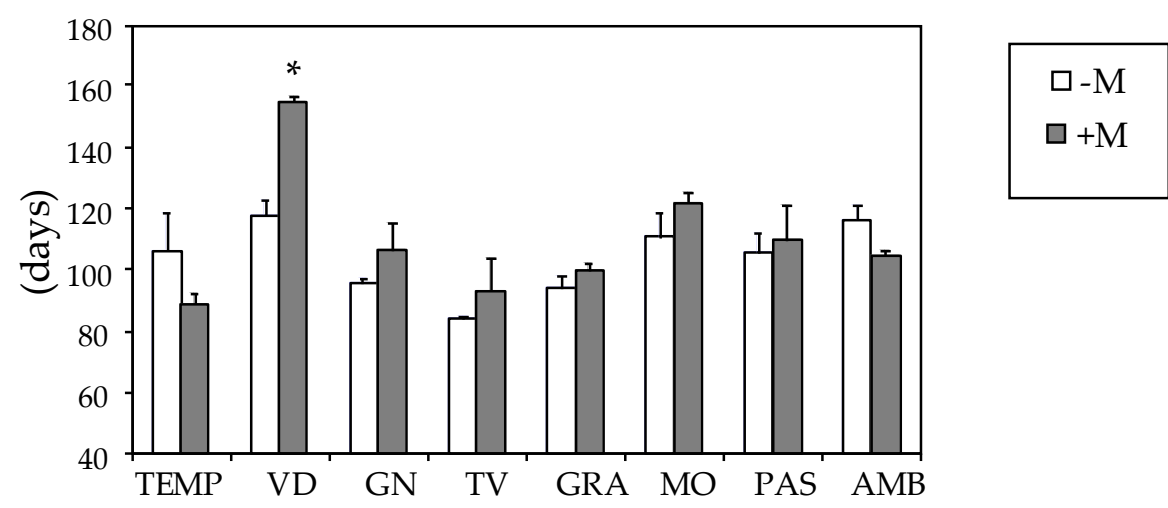

TEMP VD GN TV GRA MO PAS AMB

Figure 4. Main phases of berry development recorded from fruit-bearing cuttings of ancient grapevine varieties inoculated with arbuscular mycorrhizal fungi (+M) or non-inoculated $(-\mathrm{M})$. Values are means \pm S.E. $(\mathrm{n}=3-4)$. Within each variety, asterisks $\left.{ }^{*}\right)$ indicate significant differences $(\mathrm{P} \leq 0.05)$ between $+\mathrm{M}$ and $-\mathrm{M}$ plants according to Duncan's test. The variety labels can be found in Table 1 . 
The bunch and berry mass were significantly differed among varieties (Table 3). AMF inoculation affected bunch and berry size with different intensity depending on the variety, as indicates the significant interaction observed between factors $(\mathrm{V} \times \mathrm{M}, \mathrm{P}<0.001$ and 0.05 , respectively). However, the relative skin mass depended mainly on the variety factor, being GRA that which achieved the highest values. Mycorrhizal inoculation was the main factor contributing to reduction of bunch and berry mass. With respect to the varieties, + M plants of PAS and AMB obtained smaller bunch mass than $-\mathrm{M}$ whereas that AMF inoculation reduced berry mass of TV and PAS (Figure 5).

Table 3. Main effects and their interaction bunch characteristics from fruit-bearing cuttings of ancient grapevine varieties inoculated with arbuscular mycorrhizal fungi $(+\mathrm{M})$ or non-inoculated $(-\mathrm{M})$. The variety labels can be found in Table 1.

\begin{tabular}{|c|c|c|c|}
\hline Varieties & $\begin{array}{c}\text { Bunch Mass (g FM } \\
\text { bunch }^{-1} \text { ) }\end{array}$ & $\begin{array}{c}\text { Berry Mass (g FM } \\
\text { berry }^{-1} \text { ) }\end{array}$ & $\begin{array}{c}\text { Relative Skin Mass (\% } \\
\text { berry FM) }\end{array}$ \\
\hline \multicolumn{4}{|l|}{ Main effects } \\
\hline \multicolumn{4}{|l|}{ Variety $(\mathrm{V})$} \\
\hline TEMP & $72.8 \mathrm{a}$ & $0.86 \mathrm{bc}$ & $20.9 \mathrm{bc}$ \\
\hline VID & $91.1 \mathrm{a}$ & $1.41 \mathrm{a}$ & $13.9 \mathrm{~d}$ \\
\hline GN & $37.5 \mathrm{~b}$ & $0.81 \mathrm{bc}$ & $16.1 \mathrm{~cd}$ \\
\hline $\mathrm{TV}$ & $65.1 \mathrm{ab}$ & $0.89 \mathrm{bc}$ & $26.0 \mathrm{~b}$ \\
\hline GRA & $39.5 b$ & $1.06 \mathrm{~b}$ & $33.6 \mathrm{a}$ \\
\hline $\mathrm{MO}$ & $67.3 \mathrm{ab}$ & $1.16 \mathrm{ab}$ & $14.6 \mathrm{~d}$ \\
\hline PAS & $91.2 \mathrm{a}$ & $0.99 \mathrm{bc}$ & $14.1 \mathrm{~d}$ \\
\hline AMB & $60.5 \mathrm{ab}$ & $0.66 \mathrm{c}$ & $17.7 \mathrm{~cd}$ \\
\hline \multicolumn{4}{|l|}{ Mycorrhization (M) } \\
\hline$-\mathrm{M}$ & $75.0 \mathrm{a}$ & $1.08 \mathrm{a}$ & $19.0 \mathrm{a}$ \\
\hline$+\mathrm{M}$ & $53.2 \mathrm{~b}$ & $0.84 \mathrm{~b}$ & $20.4 a^{1}$ \\
\hline \multicolumn{4}{|l|}{ ANOVA $^{2}$} \\
\hline Variety $(\mathrm{V})$ & $* * *$ & $* * *$ & $* * *$ \\
\hline Mycorrhization (M) & $* * *$ & $* * *$ & ns \\
\hline $\mathrm{V} \times \mathrm{M}$ & $* * *$ & * & ns \\
\hline
\end{tabular}

${ }^{1}$ Values represent means $(\mathrm{n}=3-4)$. Within columns, means followed by the same letter do not differ significantly $(p \geq 0.05)$ according to Duncan's test as affected by the main factors variety $(\mathrm{V})$, mycorrhization $(\mathrm{M})$ and their interaction $(\mathrm{V} \times \mathrm{M}){ }^{2}$ Significance of the analysis of variance (ANOVA): ${ }^{*} p<0.05 ;{ }^{* * *} p<0.001$; ns, not significant $(p \geq 0.05) .{ }^{3} \mathrm{FM}$ indicates fresh matter. 

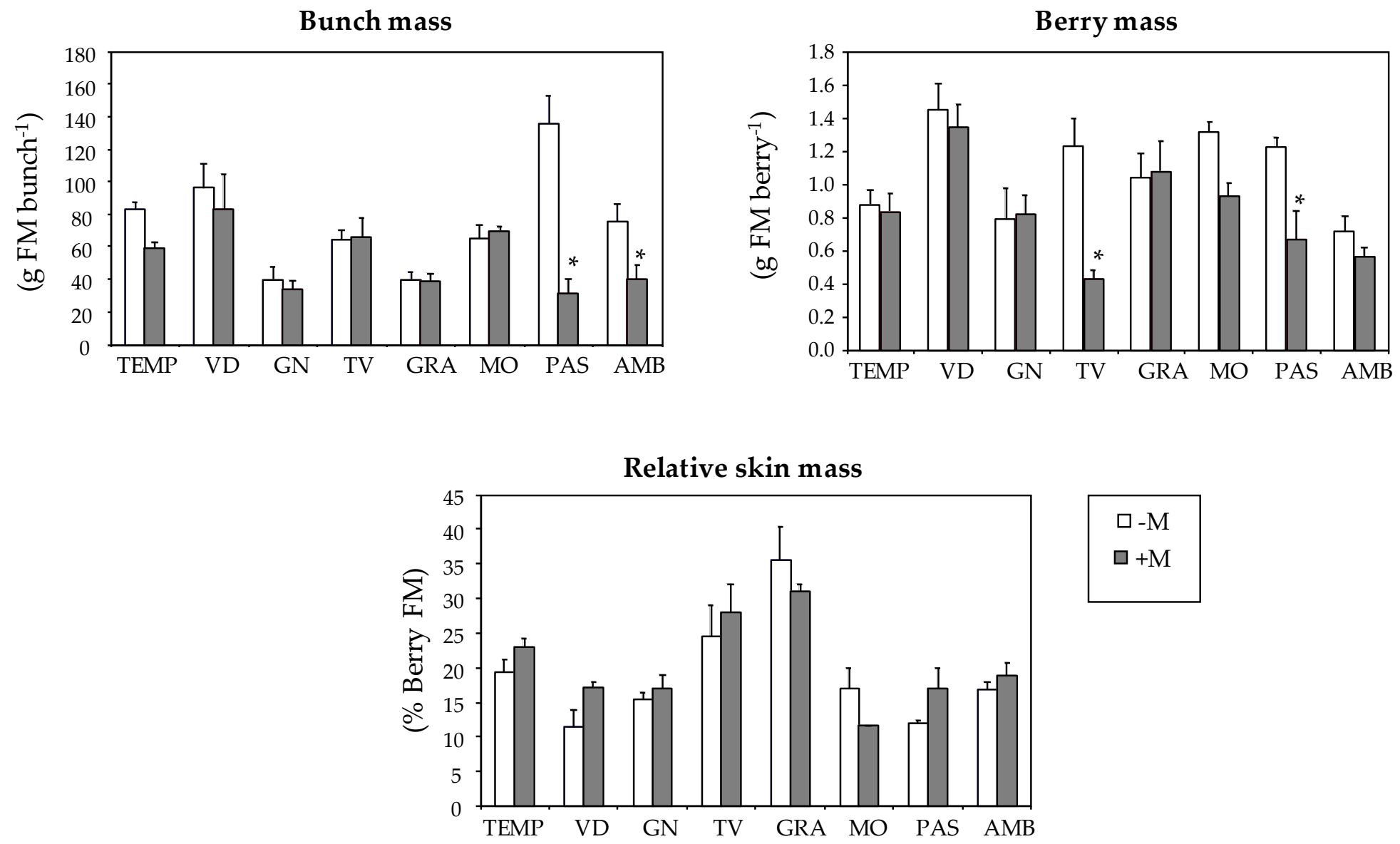

Figure 5. Bunch characteristics from fruit-bearing cuttings of ancient grapevine varieties inoculated with arbuscular mycorrhizal fungi (+M) or non-inoculated (-M). Values are means \pm S.E. $(n=3-4)$. Within each variety, asterisks $\left(^{*}\right)$ indicate significant differences $(p \leq 0.05)$ between $+\mathrm{M}$ and $-\mathrm{M}$ plants according to Duncan's test. The variety labels can be found in Table 1 . 


\subsection{Berry Composition}

The variety was the main factor modifying most of the traits related to organic acids content (must $\mathrm{pH}$, titratable acidity and malic acid) whereas the AMF inoculation resulted in a high concentration of total soluble sugars (Table 4), which was significantly increased in +M plants of GN, PAS and AMB (Figure 6). Regarding the varieties, TV had the highest values of titratable acidity and malic acid, whereas VD had the lowest titratable acidity level along the highest must $\mathrm{pH}$ (Table 4). The effect of AMF inoculation on the chromatic characteristics of must (colour density and tonality index) varied depending on the cultivar, as indicates the significant interaction between these factors $(\mathrm{V} \times \mathrm{M}, p<0.001$ and 0.05 , respectively). Specifically, AMF inoculation contributed significantly to the reduction of must tonality in TEMP, GN, PAS and AMB. The colour density was differentially affected by mycorrhiza, increasing in TV and decreasing in VD and MO.

Table 4. Main effects and their interaction on must characteristics from fruit-bearing cuttings of ancient grapevine varieties inoculated with arbuscular mycorrhizal fungi $(+\mathrm{M})$ or non-inoculated $(-\mathrm{M})$. The variety labels can be found in Table 1.

\begin{tabular}{|c|c|c|c|c|c|c|}
\hline Varieties & $\begin{array}{l}\text { Total Soluble } \\
\text { Solids ( }{ }^{\circ} \text { Brix) }\end{array}$ & Must pH & $\begin{array}{l}\text { Titratable Acidity } \\
\qquad\left(\mathrm{g} \mathrm{L}^{-1}\right)\end{array}$ & $\begin{array}{l}\text { Malic Acid } \\
\quad\left(\mathrm{g} \mathrm{L} \mathrm{L}^{-1}\right)\end{array}$ & $\begin{array}{l}\text { Colour Density } \\
\text { (AU) }{ }^{3}\end{array}$ & $\begin{array}{l}\text { Tonality } \\
\text { Index }\end{array}$ \\
\hline \multicolumn{7}{|l|}{ Main effects } \\
\hline \multicolumn{7}{|l|}{ Variety (V) } \\
\hline TEMP & $21.4 \mathrm{a}$ & $3.50 \mathrm{~b}$ & $6.45 \mathrm{~b}$ & $5.43 \mathrm{a}$ & $5.8 \mathrm{c}$ & $1.09 \mathrm{ab}$ \\
\hline VID & $21.3 \mathrm{a}$ & $3.80 \mathrm{a}$ & $3.49 c$ & $2.51 \mathrm{~b}$ & $7.0 \mathrm{c}$ & $0.93 \mathrm{abc}$ \\
\hline GN & $21.8 \mathrm{a}$ & $3.28 \mathrm{~b}$ & $6.75 \mathrm{~b}$ & $2.97 \mathrm{~b}$ & $19.5 \mathrm{a}$ & $0.89 \mathrm{bcd}$ \\
\hline TV & $21.5 \mathrm{a}$ & $3.18 \mathrm{~d}$ & $8.89 \mathrm{a}$ & $6.04 \mathrm{a}$ & $14.8 \mathrm{~b}$ & $0.72 \mathrm{~cd}$ \\
\hline GRA & $20.8 \mathrm{a}$ & $3.36 \mathrm{bcd}$ & $6.84 \mathrm{~b}$ & $3.07 \mathrm{~b}$ & $14.6 \mathrm{~b}$ & $0.63 \mathrm{~d}$ \\
\hline $\mathrm{MO}$ & $21.3 \mathrm{a}$ & $3.47 \mathrm{bc}$ & $5.59 \mathrm{~b}$ & $3.26 \mathrm{~b}$ & $20.8 \mathrm{a}$ & $1.17 \mathrm{a}$ \\
\hline PAS & $23.1 \mathrm{a}$ & $3.50 \mathrm{~b}$ & $5.95 \mathrm{~b}$ & $3.59 \mathrm{~b}$ & $11.7 \mathrm{~b}$ & $0.94 \mathrm{abc}$ \\
\hline AMB & $22.5 \mathrm{a}$ & $3.20 \mathrm{~d}$ & $5.98 \mathrm{~b}$ & $2.41 \mathrm{~b}$ & $12.9 \mathrm{~b}$ & $0.83 \mathrm{bcd}$ \\
\hline \multicolumn{7}{|l|}{ Mycorrhization (M) } \\
\hline$-\mathrm{M}$ & $21.4 \mathrm{~b}$ & $3.42 \mathrm{a}$ & $6.37 \mathrm{a}$ & $3.89 \mathrm{a}$ & $13.4 \mathrm{a}$ & $0.98 \mathrm{a}$ \\
\hline$+\mathrm{M}$ & $22.1 \mathrm{a}$ & $3.41 \mathrm{a}$ & $6.07 \mathrm{a}$ & $3.36 \mathrm{a}$ & $13.3 \mathrm{a}$ & $0.79 b^{1}$ \\
\hline \multicolumn{7}{|l|}{ ANOVA $^{2}$} \\
\hline Variety $(\mathrm{V})$ & ns & $* * *$ & $* * *$ & $* * *$ & $* * *$ & $* * *$ \\
\hline Mycorrhization (M) & $* *$ & ns & ns & ns & ns & $* * *$ \\
\hline $\mathrm{V} \times \mathrm{M}$ & ns & ns & ns & ns & $* * *$ & * \\
\hline
\end{tabular}

${ }^{1}$ Values represent means $(n=3-4)$. Within columns, means followed by the same letter do not differ significantly $(p \geq 0.05)$ according to Duncan's test as affected by the main factors variety $(\mathrm{V})$, mycorrhization $(\mathrm{M})$ and their interaction $(\mathrm{V} \times \mathrm{M}) .{ }^{2}$ Significance of the analysis of variance $(A N O V A):{ }^{*} p<0.05 ;{ }^{* *} p<0.01 ;{ }^{* * *} p<0.001$; ns, not significant $(p \geq 0.05) .{ }^{3} \mathrm{AU}$ indicates absorbance units.

Regarding phenolic composition, data from the current study showed that the total phenolic content (TPI) diminished in response to AMF inoculation, but such reducing effect was variety-specific, TV, GRA, and MO being the most responsive cultivars (Figure 7). This differential pattern was emphasized by two-way ANOVA showing significant $\mathrm{V} \times \mathrm{M}$ interaction $(p<0.05)$ (Table 5$)$. In addition, the anthocyanin content was also significantly modified by AMF inoculation, and $+\mathrm{M}$ plants accumulated more anthocyanins in berries than $-\mathrm{M}$ plants in most cases, even though the extent of the effect was dependent on variety $(\mathrm{V} \times \mathrm{M}, p<0.001)$. GRA was the variety with the highest concentration of anthocyanins whereas VD was the sole variety in which anthocyanin synthesis was negatively affected by AMF inoculation (Figure 7). Similarly, a clear interaction between the two factors was observed for extractable anthocyanins and their extractability (EA) applied $(\mathrm{V} \times \mathrm{M}, p<0.001)$ (Table 5). Thus, significant increases of EA were detected in + M plants of TEMP, MO, PAS, and AMB, whereas in VD, the opposite effect was detected (Figure 7). The presence of AMF did not affect the seed maturity (SM) index. Finally, the anthocyanin to soluble solids ratio was modulated by the two factors (variety and AMF inoculation), with a significant interaction between them $(\mathrm{V} \times \mathrm{M}, p<0.01)$. Regarding the mycorrhization, the ratio between total anthocyanins and soluble solids was significantly higher in $+\mathrm{M}$ plants than in $-\mathrm{M}$ of most of the varieties tested (TEMP, TV, GRA, PAS, and AMB). 

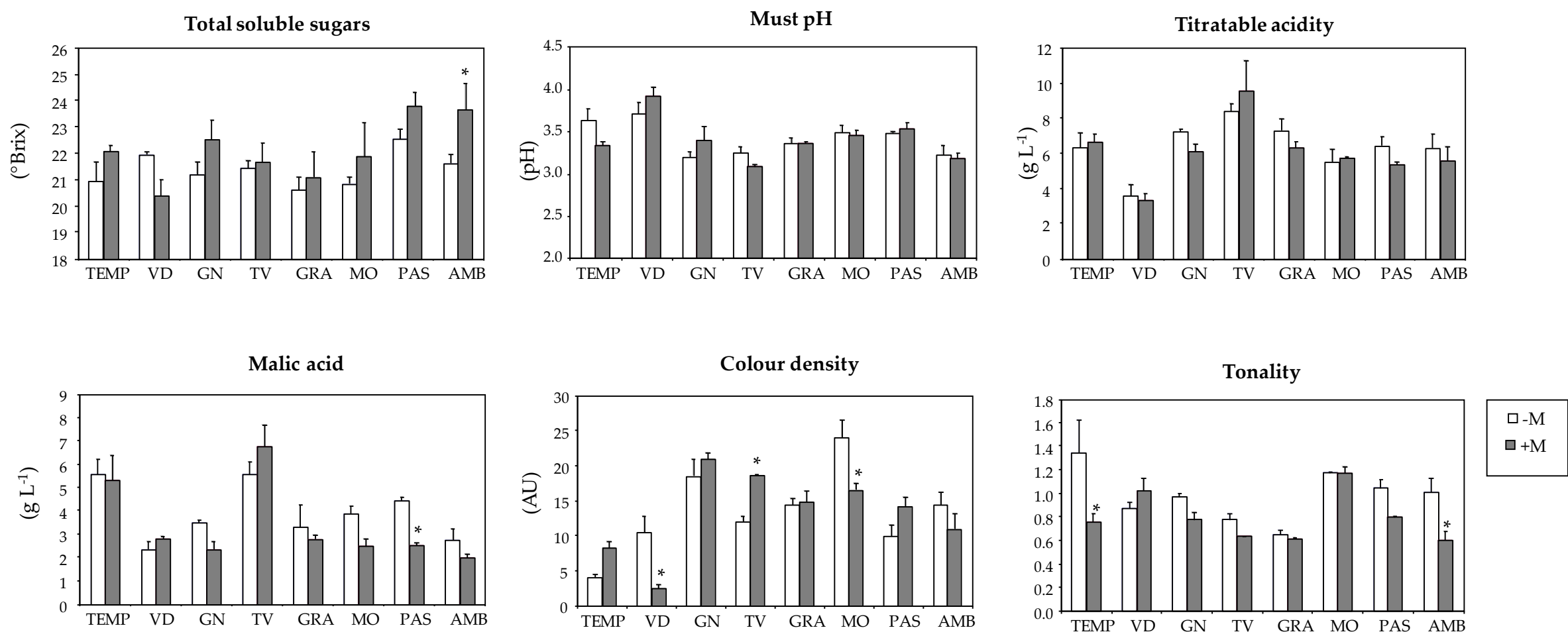

Figure 6. Must characteristics from fruit-bearing cuttings of ancient grapevine varieties inoculated with arbuscular mycorrhizal fungi (+M) or non-inoculated (-M). Values are means \pm S.E. $(n=3-4)$. Within each variety, asterisks $\left(^{*}\right)$ indicate significant differences $(p \leq 0.05)$ between $+\mathrm{M}$ and $-\mathrm{M}$ plants according to Duncan's test. The variety labels can be found in Table 1 . AU means absorbance units. 
TPI

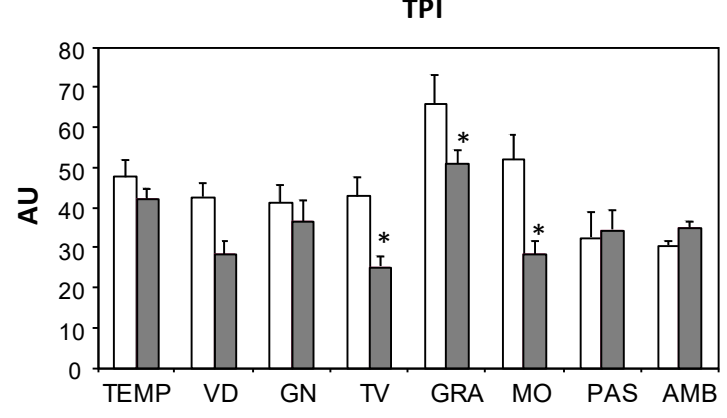

EA

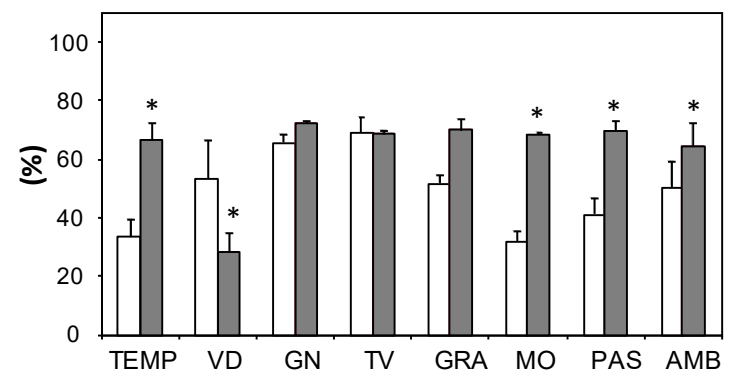

Total anthocyanins

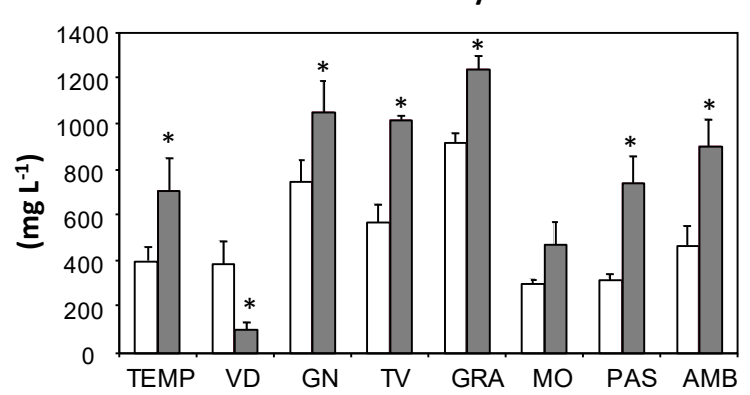

SM

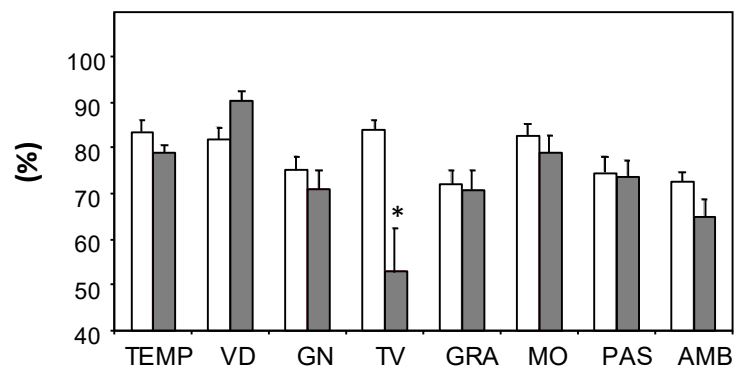

Extractable anthocyanins
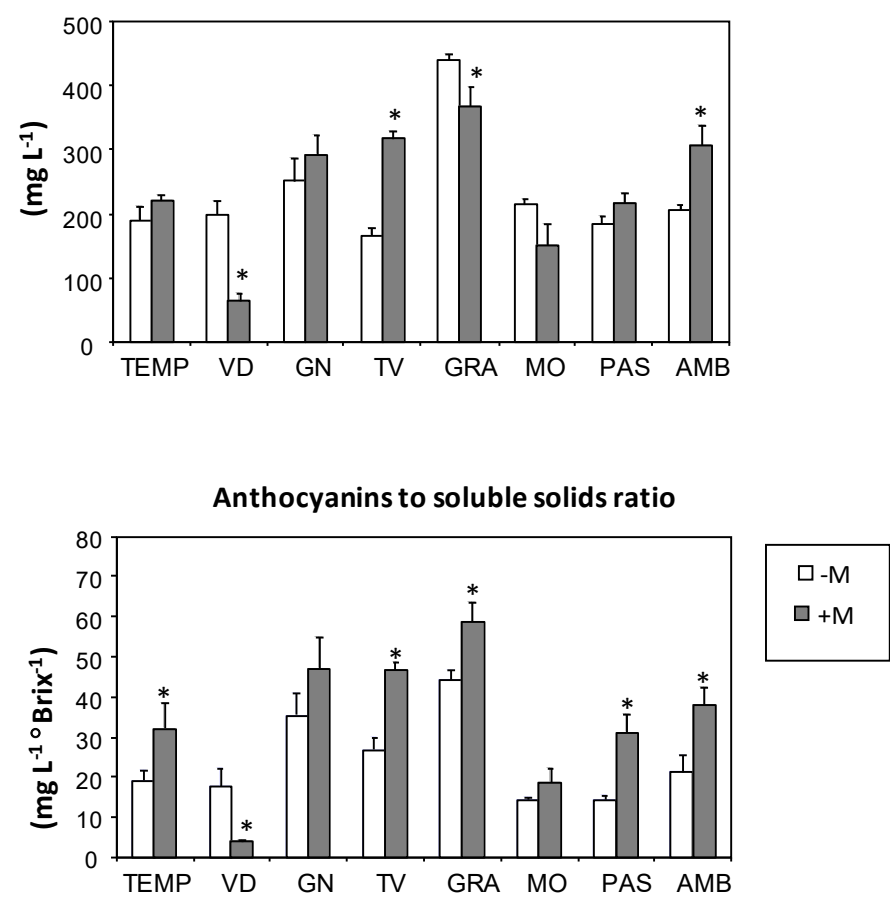

Figure 7. Phenolic composition of berries from fruit-bearing cuttings of ancient grapevine varieties inoculated with arbuscular mycorrhizal fungi (+M) or non-inoculated $(-\mathrm{M})$. Values are means \pm S.E. $(n=3-4)$. Within each variety, asterisks $\left(^{*}\right)$ indicate significant differences $(p \leq 0.05)$ between $+\mathrm{M}$ and $-\mathrm{M}$ plants according to Duncan's test. The variety labels can be found in Table 1. TPI: total polyphenol index; EA: cellular extractability of anthocyanins; SM: seed maturity; AU: absorbance units. 
Table 5. Main effects and their interaction on phenolic composition from fruit-bearing cuttings of ancient grapevine varieties inoculated with arbuscular mycorrhizal fungi (+M) or non-inoculated (-M). The variety labels can be found in Table 1 .

\begin{tabular}{|c|c|c|c|c|c|c|}
\hline Varieties & $\begin{array}{c}\mathrm{TPI}^{3} \\
\text { (AU) }^{4}\end{array}$ & $\begin{array}{c}\text { Total } \\
\text { Anthocyanins } \\
\left(\mathrm{mg} \mathrm{L}^{-1}\right)\end{array}$ & $\begin{array}{l}\text { Extractable } \\
\text { Anthocyanins } \\
\left(\mathrm{mg} \mathrm{L}^{-1}\right)\end{array}$ & $\mathrm{EA}^{5}(\%)$ & $\mathrm{SM}^{6}(\%)$ & $\begin{array}{c}\text { Anthocyanin/Soluble } \\
\text { Solids (mg L }{ }^{-1} \\
\left.{ }^{\circ} \text { Brix }^{-1}\right)\end{array}$ \\
\hline \multicolumn{7}{|l|}{ Main effects } \\
\hline \multicolumn{7}{|l|}{ Variety (V) } \\
\hline TEMP & $45.3 \mathrm{~b}$ & $527.4 \mathrm{~cd}$ & $202.0 \mathrm{bcd}$ & $47.8 \mathrm{~b}$ & $81.6 \mathrm{ab}$ & 24.4 cde \\
\hline VID & $36.5 \mathrm{bc}$ & $261.1 \mathrm{~d}$ & $139.5 \mathrm{~d}$ & $42.5 \mathrm{~b}$ & $85.6 \mathrm{a}$ & $11.6 \mathrm{f}$ \\
\hline GN & 39.2 bc & $871.6 \mathrm{ab}$ & $268.4 \mathrm{~b}$ & $68.3 \mathrm{a}$ & $73.4 \mathrm{bcd}$ & $40.3 \mathrm{ab}$ \\
\hline TV & $35.1 \mathrm{bc}$ & $758.5 \mathrm{bc}$ & $230.0 \mathrm{bc}$ & $68.9 \mathrm{a}$ & $70.8 \mathrm{~cd}$ & $35.2 \mathrm{bc}$ \\
\hline GRA & $59.5 \mathrm{a}$ & $1048.5 \mathrm{a}$ & $407.4 \mathrm{a}$ & $59.4 \mathrm{ab}$ & $71.5 \mathrm{bcd}$ & $50.5 \mathrm{a}$ \\
\hline $\mathrm{MO}$ & $41.8 \mathrm{bc}$ & $370.5 \mathrm{~d}$ & $186.4 \mathrm{~cd}$ & $47.2 \mathrm{~b}$ & $81.1 \mathrm{abc}$ & $16.1 \mathrm{ef}$ \\
\hline PAS & $33.0 \mathrm{bc}$ & $495.6 \mathrm{~cd}$ & $197.4 \mathrm{bcd}$ & $53.2 \mathrm{ab}$ & $74.2 \mathrm{bcd}$ & 21.3 def \\
\hline AMB & $32.2 \mathrm{c}$ & $649.5 \mathrm{bc}$ & $248.4 \mathrm{bc}$ & $56.2 \mathrm{ab}$ & $69.3 \mathrm{~d}$ & $28.5 \mathrm{~cd}$ \\
\hline \multicolumn{7}{|l|}{$\begin{array}{l}\text { Mycorrhization } \\
\text { (M) }\end{array}$} \\
\hline$-\mathrm{M}$ & $44.3 \mathrm{a}$ & $509.7 \mathrm{~b}$ & $230.3 \mathrm{a}$ & $49.5 \mathrm{~b}$ & $78.3 \mathrm{a}$ & $24.0 \mathrm{~b}$ \\
\hline$+\mathrm{M}$ & $35.1 \mathrm{~b}$ & 773.7 a & $241.1 \mathrm{a}$ & $63.4 \mathrm{a}$ & $72.7 \mathrm{a}$ & $34.5 \mathrm{a}^{1}$ \\
\hline \multicolumn{7}{|l|}{ ANOVA $^{2}$} \\
\hline Variety (V) & $* * *$ & $* * *$ & $* * *$ & $* * *$ & $* * *$ & $* * *$ \\
\hline $\begin{array}{l}\text { Mycorrhization } \\
\text { (M) }\end{array}$ & $* * *$ & $* * *$ & ns & $* * *$ & ns & $* * *$ \\
\hline $\mathrm{V} \times \mathrm{M}$ & * & $* *$ & $* * *$ & $* * *$ & ns & $* *$ \\
\hline
\end{tabular}

${ }^{1}$ Values represent means $(\mathrm{n}=3-4)$. Within columns, means followed by the same letter do not differ significantly $(p \geq$ $0.05)$ according to Duncan's test as affected by the main factors variety $(\mathrm{V})$, mycorrhization $(\mathrm{M})$ and their interaction $(\mathrm{V} \times \mathrm{M}) .{ }^{2}$ Significance of the analysis of variance (ANOVA): ${ }^{*} p<0.05 ;{ }^{* *} p<0.01 ; * * *<0.001$; ns, not significant $(p \geq$ 0.05). ${ }^{3}$ TPI: total polyphenol index; ${ }^{4}$ AU: absorbance units; ${ }^{5}$ EA: cellular extractability of anthocyanins; ${ }^{6}$ SM: seed maturity.

\section{Discussion}

The characterization of berry quality of ancient grapevine varieties could play an important role in the future climate scenario, considering their specific wine profiles and capacity to adapt to climatic conditions $[12,43]$. The eight ancient cultivars tested in the present study could be fully distinguished by traits as the length of the reproductive cycle, bunch mass, must $\mathrm{pH}$, titratable acidity, total and extractable anthocyanins, relative skin mass and the anthocyanin to soluble solids ratio (Figure 2). According to these results, GRA and TV stood out for having some interesting characteristics, such as higher total and extractable anthocyanin concentrations. Arbuscular mycorrhizal fungi (AMF) present in vineyard soils [14,15] are, from both ecological and economic point of view, a key component for obtaining high-quality wines $[17,44]$. The PCA analysis represented in Figure 3 shows that AMF colonization tended to accentuate the differences among varieties, being VD and TV the varieties that most clearly separated from the rest. The former, due to a longer fruit-set maturity period and higher $\mathrm{pH}$ values, and the later mainly due to higher anthocyanin levels. On the other hand, the analysis of the effects exerted by the main factors on fruit characteristics (Table 3) showed that application of AMF caused the reduction of bunch mass associated with a reduced berry size, maybe as a consequence of the sink of photosyntates from leaves to the roots colonized by AMF [26]. When studied separately (Figure 5), the varieties TV, PAS and AMB appeared as the most affected by AMF in terms of reduction of bunch and/or berry size.

Sugars and organic acids are the metabolites of most interest to winegrowers because they determine the ethanol to acidity ratio after yeast fermentation, which is a primary factor of wine quality [45]. Thereby, the concentration of total soluble solids is still the most used parameter to assess ripening, though such value is indeed variety-dependent [46], as illustrated in Figure 6. The association of grapevines with AMF resulted in a higher accumulation of sugars in berries of GN, PAS and AMB, 
but no changes were detected in TEMP, VD, TV, GRA and MO. Similarly, other studies $[20,47]$ found no significant differences between $+\mathrm{M}$ and $-\mathrm{M}$ on soluble solids-, but obviously, such effect depends on the variety. Moreover, both organic acids content and must $\mathrm{pH}$ were not affected by the presence of AMF in roots of any varieties assayed, which agrees with the above-mentioned studies (Figure 6).

Polyphenols are the principal compounds in the determination of wine style and quality, and are related to the wine consumption benefits due to their antioxidant and free radical scavenging properties $[48,49]$. Polyphenols accumulate mainly in the skin during fruit development, and comprise mainly flavonols, flavan-3-ols (when organized into polymers are called proanthocyanidins or condensed tannins) and anthocyanins. Our study shows that the AMF symbiosis exerted a negative effect on TPI, which was especially accentuated in TV, GRA and MO (Table 5, Figure 7), which contrasts with the increased TPI levels in berries of the commercial variety Tempranillo when associated with AMF [25]. This finding emphasizes the genetic diversity provided by the old grapevine varieties recovered in the Iberian Peninsula. Nevertheless, the total anthocyanin content was improved by AMF in most of the varieties (Figure 7), in concordance with previous findings of Torres et al. [20] in several clones of Tempranillo, which indicates that AMF induced the reduction of other soluble phenolic compounds different from anthocyanins in the old varieties tested in the present study. In red varieties, berry colour results from the biosynthesis and vacuolar accumulation of anthocyanins in berry skin cells from veraison, and plays an essential role in wine quality [50]. There are many studies demonstrating that the association of plants with AMF stimulates the biosynthesis of secondary metabolites (such as resveratrol, flavonols, and anthocyanins), which contributes to enhancing fruit quality $[19,44,51]$. However, these beneficial effects of AMF were not a general pattern, as indicates the loss of colour in VD and MO related to reduced anthocyanin content and to decreased TPI, respectively (Figures 6 and 7).

During winemaking, the overall concentration of phenolic compounds in berries is not the only important factor, but also their structure and capacity to be extracted during the process. Our approach has included the measurement of extractable anthocyanins and estimations of cellular extractability of anthocyanins (EA) and seed maturity (SM) (Figure 7). Usually, EA index ranges between $10 \%$ and $80 \%$ and it decreases throughout maturity. The association with AMF increased EA in comparison to -M plants (Table 5), which suggests a lower potential of colour extraction in this treatment [40]. Indeed, in TEMP and PAS, the increase of EA counterbalanced the improvement in total anthocyanins, thus extractable anthocyanins were similar in berries of $+\mathrm{M}$ and $-\mathrm{M}$ plants. By contrast, in TV and AMB, the extractable anthocyanins were improved in mycorrhized plants regardless of EA values. The higher $\mathrm{EA}$ in $+\mathrm{M}$ of $\mathrm{MO}$ was not associated with significant changes in total or extractable anthocyanins with respect to $-\mathrm{M}$ plants.

The anthocyanin to soluble solids ratio has been utilized as a good indicator of the coupling between pulp and skin evolution during berry ripening [3]. Although this ratio differed significantly between the varieties analyzed, AMF inoculation contributed to its increase (Table 5), indicating that, in general, anthocyanins accumulated faster than soluble solids in the berries of $+\mathrm{M}$ plants (Figure 7). These results support the existence of additional factors favoring increased quantities of anthocyanins in $+M$ plants $[23,24]$. Finally, bearing in mind that the global warming associated with climate change is decoupling the accumulation of anthocyanins and sugars in berries, changing the colour-alcohol balance of wines [3], results presented here suggest that the association of grapevines with AMF in old vineyards could contribute to maintain the anthocyanin to soluble solids balance under the future climate conditions.

\section{Conclusions}

This research has evaluated the influence of mycorrhizal symbiosis on yield and berry quality of some grapevines recovered from old vineyards. Overall, mycorrhization resulted in lower bunch and berry mass and in certain modifications of berry characteristics, which assisted in decreasing phenolic content and improving the accumulation of soluble sugars and anthocyanins. The findings 
of this study provide evidence that intraspecific diversity of old grapevines led to different abilities to respond to AMF association. Consequently, the differences in performance among the genotypes studied increased appreciably as a result of AMF association. Under our experimental conditions, the benefits of mycorrhization were particularly evident in GN, TV, PAS, and AMB, but some attributes of berries in $\mathrm{MO}$ and, especially, in VD were not improved by their association with AMF. This research also offers the first evidence on the winemaking potential of these old varieties of grapevines. However, further studies including rootstocks are needed to corroborate the conclusions obtained with the model of fruit-bearing cuttings, so that extrapolations to field-grown grapevines should be made with due caution.

Author Contributions: Conceptualization, M.C.A. and N.G.; methodology, M.C.A. and N.G.; investigation, D.I. and L.U.; resources, J.J.I. and M.C.A.; data curation, M.C.A. and I.P.; writing-original draft preparation, M.C.A. and N.G.; writing-review and editing, M.C.A., N.G. and I.P.; supervision, M.C.A. and N.G.; project administration, M.C.A. and J.J.I.; funding acquisition, J.J.I. and M.C.A. All authors have read and agreed to the published version of the manuscript.

Funding: This research was funded by FUNDACIÓN UNIVERSITARIA DE NAVARRA (2018).

Acknowledgments: The authors thank H. Santesteban and A. Urdiáin for their help in the design, setup and maintenance of the experimental facilities, and M. Oyarzun for assistance during measurements.

Conflicts of Interest: The authors declare no conflict of interest.

\section{References}

1. OIV Organisation Internationale de la Vigne et du Vin. State of the Vitiviniculture World Market in 2018. Available online: www.oiv.int (accessed on 7 September 2019).

2. Sweetman, C.; Sadras, V.O.; Hancock, R.D.; Soole, K.L.; Ford, C.M. Metabolic effects of elevated temperature on organic acid degradation in ripening Vitis vinifera fruit. J. Exp. Bot. 2014, 65, 5975-5988. [CrossRef]

3. Sadras, V.O.; Morán, M.A. Elevated temperature decouples anthocyanins and sugars in berries of Shiraz and Cabernet Franc. Aust. J. Grape Wine Res. 2012, 18, 115-122. [CrossRef]

4. Morales-Castilla, I.; García de Cortázar-Atauri, I.; Cook, B.I.; Lacombe, T.; Parker, A.; van Leeuwen, C.; Nicholas, K.A.; Wolkovich, E.M. Diversity buffers winegrowing regions from climate change losses. Proc. Natl. Acad. Sci. USA 2020, 117, 2864-2869. [CrossRef]

5. Eyduran, S.P.; Akin, M.; Ercisli, S.; Eyduran, E.; Maghradze, D. Sugars, organic acids, and phenolic compounds of ancient grape cultivars (Vitis vinifera L.) from Igdir province of Eastern Turkey. Biol. Res. 2015, 48, 2. [CrossRef]

6. Loureiro, M.D.; Moreno-Sanz, P.; Suárez, B. Agronomical characterization of minority grapevine cultivars from Asturias (Spain). Ciéncia Téc. Vitiv. 2017, 32, 102-114. [CrossRef]

7. Labagnara, T.; Bergamini, C.; Caputo, A.R.; Cirigliano, P. Vitis vinifera L. germplasm diversity: a genetic and ampelometric study in ancient vineyards in the South of Basilicata region (Italy). Vitis 2018, 57, 1-8.

8. Balda, P.; Ibáñez, J.; Sancha, J.C.; Martínez de Toda, F. Characterization and identification of minority red grape varieties recovered in Rioja, Spain. Am. J. Enol. Vitic. 2014, 65, 148-152. [CrossRef]

9. Urrestarazu, J.; Miranda, C.; Santesteban, L.G.; Royo, J.B. Recovery and identification of grapevine varieties cultivated in old vineyards from Navarre (Northeastern Spain). Sci. Hortic. 2015, 191, 65-73. [CrossRef]

10. Jiménez, C.; Peiró, R.; Yuste, A.; García, J.; Martínez-Gil, F.; Gisbert, C. Looking for old grapevine varieties. Vitis 2019, 58, 59-60.

11. Ocete, C.A.; Arroyo, R.; Lovicu, G.; Rodríguez-Miranda, A.; Valle, J.M.; Cantos, M.; García, J.L.; Lara, M.; González de Canales, F.; Llompart, J.; et al. An inventory of the relic Eurasian wild grapevine populational nuclei in Huelva province (Andalusia, Spain). Vitis 2019, 58, 53-57.

12. Ibáñez, J.; Carreño, J.; Yuste, J.; Martínez-Zapater, J. Grapevine breeding and clonal selection programs in Spain. In Grapevine Breeding Programs for the Wine Industry; Elsevier: Sawston, UK, 2015; pp. 183-209.

13. Martínez de Toda, F.; García, J.; Balda, P. Preliminary results on forcing vine regrowth to delay ripening to a cooler period. Vitis $\mathbf{2 0 1 9}, 58,17-22$. 
14. Balestrini, R.; Magurno, F.; Walker, C.; Lumini, E.; Bianciotto, V. Cohorts of arbuscular mycorrhizal fungi (AMF) in Vitis vinifera, a typical Mediterranean fruit crop. Environ. Microbiol. Rep. 2010, 3, 594-604. [CrossRef] [PubMed]

15. Ocete, R.; Armendáriz, I.; Cantos, M.; Álvarez, D.; Azcón, R. Ecological characterization of wild grapevine habitats focused on arbuscular mycorrhizal symbiosis. Vitis 2015, 54, 207-211.

16. Schreiner, R.P. Mycorrhizal colonization of grapevine rootstocks under field conditions. Am. J. Enol. Vitic. 2003, 54, 143-149.

17. Popescu, G.C. Arbuscular mycorrhizal fungi-an essential tool to sustainable vineyard development: a review. Curr. Trends Nat. Sci. 2016, 5, 107-116.

18. Torres, N.; Goicoechea, N.; Zamarreño, A.; Antolín, M.C. Mycorrhizal symbiosis affects ABA metabolism during berry ripening in Vitis vinifera L. cv. Tempranillo grown under climate change scenarios. Plant. Sci. 2018, 274, 383-393. [CrossRef]

19. Avio, L.; Turrini, A.; Giovannetti, M.; Sbrana, C. Designing the ideotype mycorrhizal symbionts for the production of healthy food. Front. Plant. Sci. 2018, 9, 1089. [CrossRef]

20. Torres, N.; Goicoechea, N.; Morales, F.; Antolín, M.C. Berry quality and antioxidant properties in Vitis vinifera cv. Tempranillo as affected by clonal variability, mycorrhizal inoculation and temperature. Crop. Past. Sci. 2016, 67, 961-977. [CrossRef]

21. Gabriele, M.; Gerardi, C.; Longo, V.; Lucejko, J.; Degano, I.; Pucci, L.; Domenici, V. The impact of mycorrhizal fungi on Sangiovese red wine production: phenolic compounds and antioxidant properties. LWT-Food Sci. Technol. 2016, 72, 310-316. [CrossRef]

22. Ponce, M.A.; Scervino, J.M.; Erra-Balsells, R.; Ocampo, J.A.; Godeas, A.M. Flavonoids from shoots and roots of Trifolium repens (white clover) grown in presence or absence of the arbuscular mycorrhizal fungus Glomus intraradices. Phytochemistry 2004, 65, 1925-1930. [CrossRef]

23. Bruisson, S.; Maillot, P.; Schellenbaum, P.; Walter, B.; Gindro, K.; Deglène-Benbrahim, L. Arbuscular mycorrhizal symbiosis stimulates key genes of the phenylpropanoid biosynthesis and stilbenoid production in grapevine leaves in response to downy mildew and grey mould infection. Phytochemistry 2016, 131, 92-99. [CrossRef] [PubMed]

24. Balestrini, R.; Salvioli, A.; DalMolin, A.; Novero, M.; Gabelli, G.; Paparelli, E.; Marroni, F.; Bonfante, P. Impact of an arbuscular mycorrhizal fungus versus a mixed microbial inoculum on the transcriptome reprogramming of grapevine roots. Mycorrhiza 2017, 27, 417-430. [CrossRef] [PubMed]

25. Torres, N.; Hilbert, G.; Antolín, M.C.; Goicoechea, N. Aminoacids and flavonoids profiling in Tempranillo berries can be modulated by the arbuscular mycorrhizal fungi. Plants 2019, 8, 400. [CrossRef] [PubMed]

26. Smith, S.E.; Read, D.J. Mycorrhizal Symbiosis, 3rd ed.; Academic Press: London, UK, 2008 ; p. 800. ISBN 9780123705266.

27. Staddon, P.L.; Fitter, A.H.; Graves, J.D. Effect of elevated atmospheric $\mathrm{CO}_{2}$ on mycorrhizal hyphal production and phosphorus inflow in Plantago lanceolata and Trifolium repens in association with the arbuscular mycorrhizal fungus Glomus mosseae. Glob. Change Biol. 1999, 5, 347-358. [CrossRef]

28. MAPA (Ministerio de Agricultura, Pesca y Alimentación). Available online: https://www.mapa.gob.es/es/ (accessed on 7 September 2019).

29. Mullins, M.G. Test-plants for investigations of the physiology of fruiting in Vitis vinifera L. Nature 1966, 209, 419-420. [CrossRef]

30. Agnolucci, M.; Battini, F.; Cristani, C.; Giovannetti, M. Diverse bacterial communities are recruited on spores of different arbuscular mycorrhizal fungal isolates. Biol. Fertil. Soils 2015, 51, 379-389. [CrossRef]

31. Trotel-Aziz, P.; Abou-Mansour, E.; Courteaux, B.; Rabenoelina, F.; Clément, C.; Fontaine, F.; Aziz, A. Bacillus subtilis PTA-271 counteracts botryosphaeria dieback in grapevine, triggering immune responses and detoxification of fungal phytotoxins. Front. Plant. Sci. 2019, 10, 25. [CrossRef]

32. Coombe, B.G. Adoption of a system for identifying grapevine growth stages. Aust. J. Grape Wine Res. 1995, 1, 104-110. [CrossRef]

33. Kliewer, W.M.; Dokoozlian, N.K. Leaf area/crop weight ratios of grapevines: influence on fruit composition and wine quality. Am. J. Enol. Vitic. 2005, 56, 170-181.

34. Ollat, N.; Gény, L.; Soyer, J.P. Les boutures fructifères de vigne: validation d'un modèle d'étude de la physiologie de la vigne. I. Principales caractéristiques de l'appareil végétatif. J. Int. Sci. Vigne Vin 1998, 32, 1-9. 
35. Koske, R.E.; Gemma, J.N. A modified procedure for staining roots to detect VA mycorrhizas. Mycol. Res. 1989, 92, 486-488. [CrossRef]

36. Giovannetti, M.; Mosse, B. An evaluation of techniques for measuring vesicular-arbuscular mycorrhizal infection in roots. New Phytol. 1980, 87, 489-500. [CrossRef]

37. OIV. Compendium of International Methods of Analysis of Wines and Musts, Vol. I; International Organisation of Vine and Wine: Paris, France, 2018; ISBN 979-10-91799-80-5.

38. Saint-Cricq, N.; Vivas, N.; Glories, Y. Maturité phénolique: définition et contrôle. Rev. Fr. d'Oenol. 1998, 173, 22-25.

39. Ribéreau-Gayon, J.; Stonestreet, E. Le dosage des anthocyanes dans le vin rouge. Bull. Soc. Chim. Fr. 1965, 9, 2649-2652.

40. Nadal, M. Phenolic maturity in red grapes. In Methodologies and Results in Grapevine Research; Delrot, S., Medrano-Gil, H., Or, E., Bavaresco, L., Grando, S., Eds.; Springer Science+Business Media, B.V.: Dordrecht, The Netherlands, 2010; pp. 389-409.

41. EEC (European Union Commission Regulation) $\mathrm{N}^{\circ}$ 2676/90. Community Methods for the Analysis; Official Journal of the European Communities: Luxemburg, 1990; L 272:1-92.

42. Glories, Y. La couleur des vins rouges. 2e partie: mesure, origine et interprétation. OENO One 1984,18, $253-271$. [CrossRef]

43. Gisbert, C.; Peiró, R.; San Pedro, T.; Olmos, A.; Jiménez, C.; García, J. Recovering ancient grapevine varieties: from genetic variability to in vitro conservation, a case study. In Grapes and Wines. Advances in Production, Processing, Analysis and Valorization; Jordão, A.M., Cosme, F., Eds.; Intechopen: London, UK, 2015; pp. 3-21.

44. Torres, N.; Antolín, M.C.; Goicoechea, N. Arbuscular mycorrhizal symbiosis as a promising resource for improving berry quality in grapevines under changing environments. Front. Plant. Sci. 2018, 9, 897. [CrossRef]

45. Ribéreau-Gayon, P.; Dubourdieu, D.; Donèche, B.; Lonvaud, A. Handbook of Enology: The Microbiology of Wine and Vinifications, 2nd ed.; Wiley \& Sons: Chichester, UK, 2006; Vol.1.

46. Poni, S.; Gatti, M.; Palliotti, A.; Dai, Z.; Duchêne, E.; Truong, T.T.; Ferrara, G.; Matarrese, M.S.; Gallotta, A.; Bellincontro, A.; et al. Grapevine quality: A multiple choice issue. Sci. Hort. 2018, 234, 445-462. [CrossRef]

47. Karagiannidis, N.; Nikolaou, N.; Ipsilantis, I.; Zioziou, E. Effects of different N fertilizers on the activity of Glomus mosseae and on grapevine nutrition and berry composition. Mycorrhiza 2007, 18, 43-50. [CrossRef]

48. Georgiev, V.; Ananga, A.; Tsolova, V. Recent advances and uses of grape flavonoids as nutraceuticals. Nutrients 2014, 6, 391-415. [CrossRef]

49. Giovinazzo, G.; Grieco, F. Functional properties of grape and wine polyphenols. Plant. Foods Hum. Nutr. 2015, 70, 454-462. [CrossRef]

50. He, F.; Mu, L.; Yan, G.-L.; Liang, N.N.; Pan, Q.H.; Wang, J.; Reeves, M.J.; Duan, C.-Q. Biosynthesis of anthocyanins and their regulation in colored grapes. Molecules 2010, 15, 9057-9091. [CrossRef] [PubMed]

51. Goicoechea, N.; Antolín, M.C. Increased nutritional value in food crops. Microb. Biotechnol. 2017, 10, 1004-1007. [CrossRef] [PubMed]

(C) 2020 by the authors. Licensee MDPI, Basel, Switzerland. This article is an open access article distributed under the terms and conditions of the Creative Commons Attribution (CC BY) license (http://creativecommons.org/licenses/by/4.0/). 